\title{
European Green Deal - the way to Circular Public Procurement
}

\section{Tünde Tátrai ${ }^{1}$ • Orsolya Diófási-Kovács ${ }^{1}$}

Accepted: 19 July 2021 / Published online: 23 August 2021

(c) The Author(s) 2021

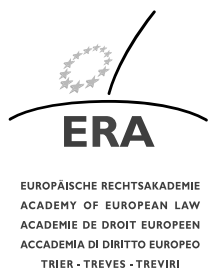

\section{Abstract}

The aim of this paper is to link the concept of green public procurement (GPP) to the nowadays popular circular economy (CE) concept by exploring the possibilities of circular public procurement. The legal framework will be specified at all stages of the suggested procurement cycle (preparation, tendering, execution, monitoring) and the connected instruments that support GPP will be summarized. In the research, ecolabelling and life-cycle costing will be highlighted as tools leading to Circular Public Procurement (CPP), drawing attention to the importance of ensuring competition and cooperation with market actors using these tools.

Keywords Circular public procurement · Circular economy · EU Green Deal

\section{Introduction}

The EU spends 14 percent of its $\mathrm{GDP}^{1}$ on public procurement, which means a significant amount of potential support for sustainability goals within the public sector. Accordingly, the significance of procurement in reaching sustainability related goals

\footnotetext{
${ }^{1}$ https://ec.europa.eu/growth/single-market/public-procurement_en\#: :text=Why\%20public\%20 procurement $\% 20$ is $\% 20$ important $\% 20$ Every $\% 20$ year $\% 2$ C $\% 20$ over,on $\% 20$ the $\% 20$ purchase $\% 20$ of $\% 20$ services $\% 2 \mathrm{C} \% 20$ works $\% 20$ and $\% 20$ supplies.
}

Tünde Tátrai, Professor, Corvinus University of Budapest.

Orsolya Diófási-Kovács, assistant professor, Corvinus University of Budapest.

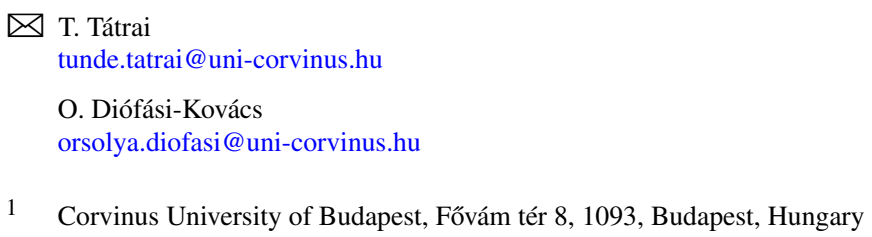


(among others, policy and strategic goals) is inevitable. The relatively new concept of circular economy in the EU seeks to achieve sustainability goals on a higher level and thus green procurement processes should also adapt to higher standards in terms of the life-cycle approach. This creates the term "circular procurement" defined by the European Commission as "an approach to green public procurement which pays special attention to the purchase of works, goods or services that seek to contribute to the closed energy and material loops within supply chains, whilst minimizing, and in the best case avoiding, negative environmental impacts and waste creation across the whole life-cycle". 2

The aim of this article is to explore the possibilities of circular public procurement, based on the above-mentioned definition. As understood, circular procurement can be considered as comprehensive green public procurement with some extra features, paying special attention to the life-cycle approach and the supply chain of the product. In practice this approach creates challenges and a strong need for collaboration to all the parties involved in public procurement and the question is raised how this new approach could be implemented efficiently, effectively and correctly in legal terms?

The legal framework will be specified at all stages of the suggested procurement cycle (preparation, tendering, execution, monitoring) with the connected instruments that support GPP will be highlighted (ecolabelling, LCC, the EU GPP Toolkit ${ }^{3}$ ) and some examples that can contribute to minimizing the environmental effects of the supply chains.

\section{The circular economy concept and public procurement}

This paper will be concentrating mostly on the green aspects of sustainable procurement and the circular economy, with awareness to the fact that "circular economy places emphasis on the redesign of processes and cycling of materials, which may contribute to more sustainable business models, but it also encapsulates tensions and limitations (e.g. include an absence of the social dimension inherent in sustainable development that limits its ethical dimensions)." ${ }^{4}$ Circular procurement is understood as an approach that recognizes the role that private and public authorities can play in supporting the transition towards a circular economy.

The European Union adopted the first Circular Economy Package at the end of 2015 , which is expected to

- "boost recycling and preventing the loss of valuable materials;

- create jobs and economic growth;

- show how new business models, eco-design and industrial symbiosis can move us towards zero-waste;

- reduce greenhouse emissions and environmental impacts."

\footnotetext{
${ }^{2}$ https://ec.europa.eu/environment/gpp/index_en.htm.

${ }^{3} \mathrm{https} / / /$ ec.europa.eu/environment/gpp/toolkit_en.htm.

${ }^{4}$ Murray et al. [14], p. 2.

${ }^{5}$ Towards a Circular Economy [21].
} 
"The general concept underlying the circular economy has been developed by many schools of thought, such as Regenerative Design, Performance Economy, Cradle to Cradle, Industrial Ecology, Biomimicry, Blue Economy, Permaculture, Natural Capitalism, Industrial Metabolism and Industrial Symbiosis."6

According to Murray et al (2015) “... Circular Economy is an economic model wherein planning, resourcing, procurement, production and reprocessing are designed and managed, as both process and output, to maximize ecosystem functioning and human well-being."7 This means in the strict sense that in case of a circular economy there should be no negative effect on the environment and by mentioning human well-being, there is an orientation towards the social aspect of sustainability.

Within the economy there are two types of material flows "...those which are biological nutrients, designed to re-enter the biosphere safely, and technical nutrients, which are designed to circulate at high quality without entering the biosphere. The aims are to 'design out' waste, return nutrients, and recycle durables, using renewable energy to power the economy."

In the circular economy concept, business models should change, meaning that "products should become fully reused or recycled, which requires reverse logistics systems, or firms should turn towards product-service system (PSS) and sell performance related to serviced products. Furthermore, products have to be made in specific processes, with recycled materials and specific resources, which may require not only specific capabilities but also creating reverse logistics systems and maintaining relationships with other companies and customers to assure closing of material loops"9 Several authors reviewed the most important components of circular business models, namely reversed supply chain logistics.

The EU Circular Economy Package ${ }^{10}$ suggests a waste hierarchy which starts with (1) Avoid-avoidance of waste, maximum conservation of resources, (2) Reusemeaning the reuse of materials, (3) Recycle-recycling and reprocessing materials downcycling should be avoided though, (4) Waste to energy-energy recovery prior to disposal (5) Disposal of waste-meaning no conservation of resources.

There are several solutions in practice to support the CE concept. These require an open mindset and willingness to strongly collaborate from both suppliers and purchasers. For the avoidance of waste, dematerialization of products could be a solution, or lean management that reduces the waste from production processes. The circular solutions can be ensured by selling the functions, not the material itself. These solutions are called Product-Service-Systems (PSS) that help dematerializing the economy and closing the material loops. PSSs have different solutions based on availability or performance. Sharing platforms, repair services, upgrading contribute to the longevity of products, thus reducing the waste generated with their consumption. Recycling programs contribute to recovering resources from disposed products or production waste.

\footnotetext{
${ }^{6}$ Lewandowski [11], p. 5.

${ }^{7}$ Murray et al. [14], p. 25.

${ }^{8}$ Murray et al. [14], p. 14.

${ }^{9}$ Lewandowski [11], p. 6.

${ }^{10}$ Towards a Circular Economy [21].
} 
Circular public procurement can significantly contribute to the wide spread of the circular business models by requiring green products and additional circularity goals in collaboration with suppliers. The circular economy goals give both parties a new challenge which requires closer collaboration between the supplier and procurer. ${ }^{11}$

\section{Green Deal and the Circular Economy Action Plan}

Based on the European Green Deal ${ }^{12}$ the Commission states, that public authorities, including the EU institutions, should lead by example and ensure that their procurement is green and the Commission will propose further legislation and guidance on green public purchasing.

According to the European Circular Economy Action Plan ${ }^{13}$ (2020) "the Commission will propose minimum mandatory green public procurement (GPP) criteria and targets in sectoral legislation and phase in compulsory reporting to monitor the uptake of Green Public Procurement (GPP) without creating unjustified administrative burden for public buyers". This goal is set for year 2021.

A number of researchers have criticised this approach ${ }^{14}$ and have also identified the problems at the grassroots level that legislators should face in making green public procurement mandatory ${ }^{15}$. A growing number of analyses are emerging that help to understand the path to $\mathrm{CPP}^{16}$. Alhola et al. ${ }^{17}$ identified a number of sectors where CPP can be successful, such as construction, waste and wastewater management, transportation, food, and catering, furniture and textiles. The study also suggests that the life-cycle approach and life cycle costing as well as criteria concerning the reuse and recycling of materials could promote circular procurement. Several researchers pointed out that cooperation between procurers and actors in the supply chains are important for the future development of circular procurement.

Overall, the researcher's interest is clearly directed towards CPP, while the lack of legal instruments or their existence is not clear to users. If the application of individual instruments does not permeate the whole process, it will not be considered circular, only the application of a single green instrument can be identified. In the following, we therefore identify the CPP model from a different perspective, specifically in terms of the available legal provisions, and consider further the pathway for the evolution of GPP into CPP for contracting entities.

${ }^{11}$ GPP Guideline [7]; Meehan and Bryde [12]; Witjes and Lozano [22].

${ }^{12}$ European Green Deal [5].

${ }^{13}$ European Circular Economy Action Plan [6].

${ }^{14}$ Halonen [9].

${ }^{15}$ Pouikli [16].

${ }^{16}$ Rosell [19]; Witjes and Lozano [22]; Kristensen et al. [10]; Ntsondé and Aggeri [15]; Rainwille [18].

${ }^{17}$ Alhola et al. [1]. 


\section{Transforming legal instruments to green procurement solutions for supporting the circular economy}

According to the EU level policies and the legal framework, we can see that a procurement process is not a linear set of activities, but rather a cycle itself. Based on the model of the PDSA cycle ${ }^{18}$, a public procurement process can be divided into four stages that follow one another consecutively (Fig. 1).

In the preparation phase (1) the contracting authority needs to analyse demand, conduct preliminary market consultation and prepare the procedural documents in a multidisciplinary team. In fact, it is at this stage where it is decided whether a real green aspect is to be implemented or whether a suitability requirement is merely stipulated in the contract notice, which may be certified by a capacity provider who is subsequently hardly involved in the performance. Consultation with market players is a key issue, as the use of green criteria is expected from contracting authorities if they do not restrict competition and reduce the number of potential bidders. Part of the circular logic is to avoid restricting competition and have more bidders in the procedures to be conducted as a result of progressive greening.

In the tendering phase (2) tenders are published, questions are answered by the contracting authority, submission of tenders is done, and evaluation of the tenders take place. As many questions may arise, for example, about ecolabelling, which are not clear to market players, it is important to answer questions at the procedural stage, or to interpret the content of the contract during the negotiation phase, for example, how the product life cycle is calculated. After the tendering phase, the evaluation stage includes an examination of the prices received, including examination of an abnormally low price, where the contracting authority may also ask for an assessment of the environmental consequences of the technology promised in the tender. The evaluation also includes the verification and substantiation of the green references, by environmental specialists, and pollution reduction methods offered, in order to establish the validity of the tender.

In the execution phase (3) the verification of the execution of the contract takes place, contractors are checked, and modifications are managed. The commitments made in the tender, and any subsequent modifications, will result in a disproportionate simplification of the commitments initially entered into, which must not lead to the cancellation of the previous green commitments. The management of the performance phase of the contract also entails the need to take account of the environmental aspects of the offer.

The monitoring phase (4) has significant importance in case of circular procurement. The evaluation of the success of the tender should take place in this phase too. The resource needs of the procurement process in terms of time, money and knowhow need to be checked, the success of the process itself evaluated, the results of the procurement in terms of sustainability (e.g. $\mathrm{CO} 2$ emissions or amount of water saved) calculated. The experiences of the procurement process are very valuable assets for the organization itself if the feedback is used in the preparation phase of the next tender, and if the information about best practices can be shared, it can support the uptake of circular public procurement by other organizations as well.

${ }^{18}$ Moen and Norman [13]. 


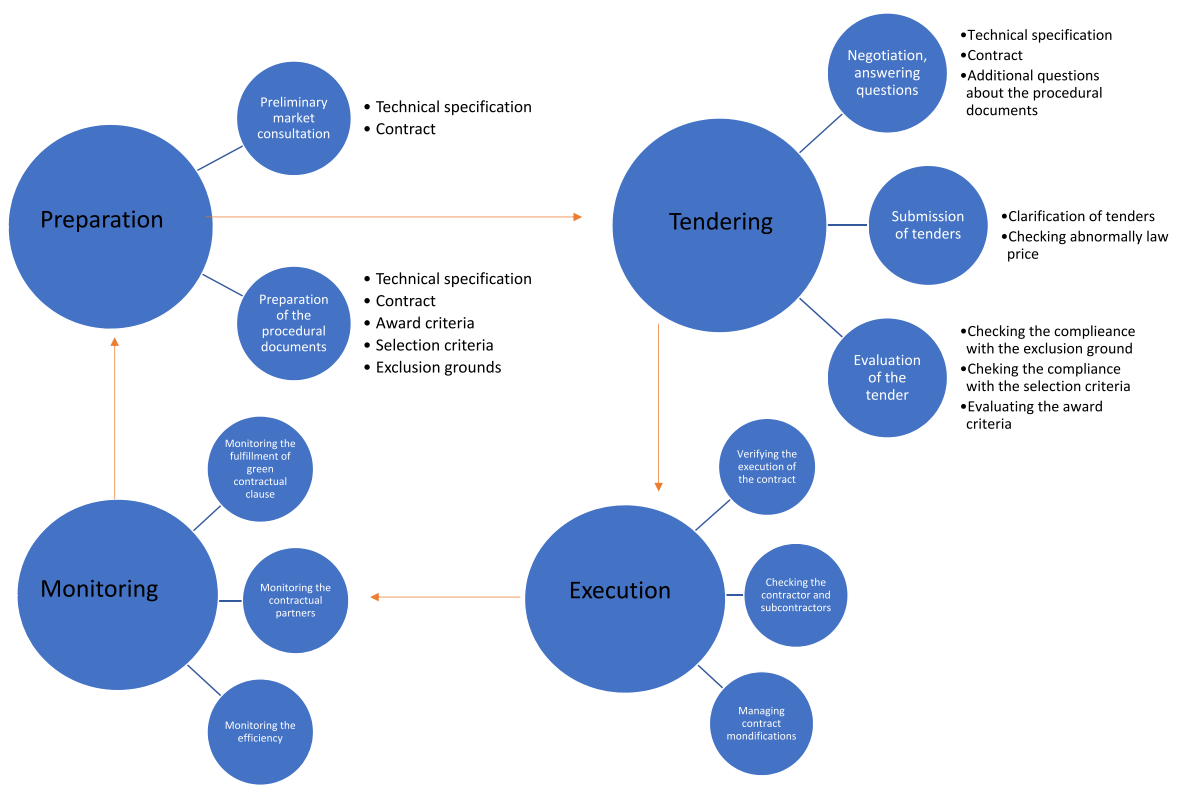

Fig. 1 Green public procurement cycle. Source: own compilation

The above activities are to be underpinned by legal instruments ${ }^{19}$ and they should assist in the direct application of the law by identifying elements that can indeed green procedures and further aspirations for CPP.

Art. 18(2) of Directive 2014/24 $4^{20}$ : Member States shall take appropriate measures to ensure that in the performance of public contracts economic operators comply with applicable obligations in the fields of environmental, social and labour law. This requirement should be referred to in the contract by contracting authorities in general terms. This is referred to in Art. 57(4) of Directive 2014/24, which also provides optional grounds for exclusion where the contracting authority has failed to comply with Art. 18(2): "Art. 57(4). Contracting authorities may exclude or may be required by Member States to exclude from participation in a procurement procedure any economic operator in any of the following situations: where the contracting authority can demonstrate by any appropriate means a violation of applicable obligations referred to in Article 18(2),"

According to the Art. 40, of Directive 2014/24 Preliminary market consultation: Before launching a procurement procedure, contracting authorities may conduct market consultations with a view to preparing the procurement and informing economic operators of their procurement plans and requirements, and seek or accept advice

\footnotetext{
${ }^{19}$ Directive 2014/24/EU of the European Parliament and of the Council of 26 February 2014 on public procurement and repealing Directive 2004/18/EC, Directive 2014/25/EU of the European Parliament and of the Council of 26 February 2014 on procurement by entities operating in the water, energy, transport and postal services sectors and repealing Directive 2004/17/EC.

${ }^{20}$ Directive 2014/24/EU of the European Parliament and of the Council of 26 February 2014 on public procurement and repealing Directive 2004/18/EC.
} 
from independent experts or authorities or from market participants. This possibility has been introduced by the existing directives, which for the first time allow parties to communicate with each other on green technological issues, stocks, etc. before starting the procedure.

The most frequently cited rule is Art. 42. of Directive 2014/24, which deals with the definition of technical specifications, and is also specifically highlighted in the regulation that the technical specifications shall be formulated for example in terms of performance or functional requirements, including environmental characteristics, provided that the parameters are sufficiently precise to allow tenderers to determine the subject-matter of the contract and to allow contracting authorities to award the contract.

Article 43. of Directive 2014/24 is about labels, which can be used in the technical specifications, the award criteria or the contract performance conditions.

In particular, Art. 44. of Directive 2014/24 is about certification, where contracting authorities may require that economic operators provide a test report from a conformity assessment body, as means of proof of conformity with requirements or criteria set out in the technical specifications, the award criteria or the contract performance conditions. For example, if a label is required in the procedure, but the economic operator does not have the label and decides to submit equal proof to the ecolabel. ${ }^{21}$

The former is complemented by Art. 62. of Directive 2014/24, which allows for the imposition of environmental management standards, where contracting authorities require the production of certificates drawn up by independent bodies attesting that the economic operator complies with certain environmental management systems or standards, they shall refer to the EMAS ${ }^{22}$ of the Union or to other environmental management systems for example ISO $14001^{23}$.

The selection criteria regulated in Art. 58. of Directive 2014/24 may relate to technical and professional ability; with regard to technical and professional ability, contracting authorities may impose requirements ensuring that economic operators possess the necessary human and technical resources and experience to perform the contract to an appropriate quality standard.

Art. 67. of Directive 2014/24 regulates the most commonly used contract award criterion, where on the one hand the most economically advantageous tender from the point of view of the contracting authority shall be identified on the basis of the price or cost, using a cost-effectiveness approach, such as life-cycle costing in accordance with Article 68, and may include the best price-quality ratio, which shall be assessed on the basis of criteria, including qualitative, environmental and/or social aspects, linked to the subject-matter of the public contract in question. Such criteria may comprise, for instance, quality, including technical merit, aesthetic and functional characteristics, accessibility, design for all users, social, environmental and innovative characteristics and trading and its conditions. The most important limit is that the award criteria shall be considered to be linked to the subject-matter of the

\footnotetext{
${ }^{21}$ See. C-368/10. Max Havelaar Case.

${ }^{22}$ EMAS = Eco-Management and Audit Scheme.

${ }^{23}$ ISO 14024:1999 (1999): Environmental labels and declarations - Type I environmental labelling - Principles and procedures, https://www.iso.org/obp/ui/\#iso:std:iso:14024:ed-1:v1:en.
} 
public contract where they relate to the works, supplies or services to be provided under that contract in any respect and at any stage of their life cycle, including factors involved in the specific process of production, provision or trading of those works, supplies or services or a specific process for another stage of their life cycle, even where such factors do not form part of their material substance.

The aforementioned life-cycle costing is regulated by Art. 68. of Directive $2014 / 24$, according to which life-cycle costing shall to the extent relevant cover parts or all of the following costs over the life cycle of a product, service or works: (a) costs, borne by the contracting authority or other users, such as: (i) costs relating to acquisition, (ii) costs of use, such as consumption of energy and other resources, (iii) maintenance costs, (iv) end of life costs, such as collection and recycling costs. (b) costs imputed to environmental externalities linked to the product, service or works during its life cycle, provided their monetary value can be determined and verified.

The rules on disproportionately low prices (Art. 69. of Directive 2014/24) indirectly allow that if it becomes clear during the price analysis that the tenderer has not included elements or activities which are justified from a green point of view and are part of the purchase requirement, the tender may be invalid.

In the Conditions for performance of contracts, Article 70 of Directive 2014/24 briefly refers to the fact that contracting authorities may lay down special conditions relating to the performance of a contract, provided that they are linked to the subject-matter of the contract and indicated in the call for competition or in the procurement documents. Those conditions may include economic, innovation-related, environmental, social or employment-related considerations.

In the case of subcontractors, tenderers are required to declare and, during performance, to ensure that they are not subject to any of the exclusion grounds. Indirectly, therefore, the extension of the exclusion grounds to subcontractors is also mandatory, which may also mean the application of Art. 18(2), depending on national legislation.

Finally, Art. 72. of Directive 2014/24 limits the modification of the contract, which may even lead to the deletion of strict environmental requirements during the performance of the contract. According to the consistent practice of the Court of Justice of the European Union, it is also necessary to consider retrospectively what the effect would have been on the parties originally competing if they had to compete on different terms.

Of the above, contracting authorities typically use the technical specification, the award criteria and the contracts clause. These abovementioned stages of a public procurement process are determined by the public procurement directives. Figure 2 shows the different phases and relevant parts of the legislation.

The legislation was designed to support the greening of tenders but due to the multidisciplinary nature of circular public procurement significant support is needed for designing this type of tenders, for example: legal expertise, technical/engineering knowledge, environmental expertise, and public procurement professionals and financial experts are usually involved in a public procurement process. Green procurement can serve as a policy tool at policy level and as a management tool at the organizational level. For this reason the EU takes reasonable efforts to promote green public procurement ${ }^{24}$, but many other countries have taken steps outside the EU as

${ }^{24}$ https://ec.europa.eu/environment/gpp/index_en.htm. 


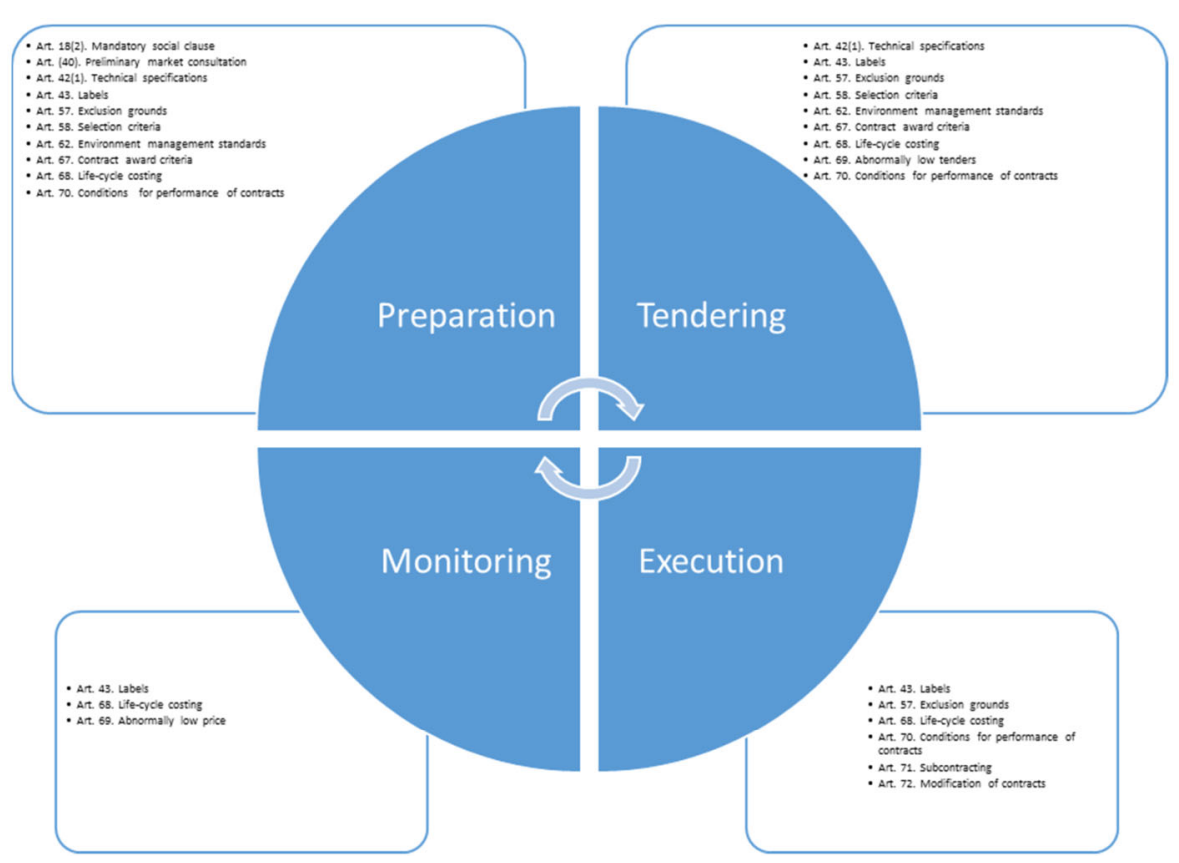

Fig. 2 Legal instruments of GPP. Source: own compilation

well to integrate sustainability criteria into their public procurement processes at both policy and management level.

In the following section we will describe how the different tools (GPP Toolkit, ecolabels, LCC) can support the uptake of CPP in light of the aforementioned legislative framework.

\section{Ecolabel and LCC towards CPP}

The basic concept of GPP relies on having clear, verifiable, justifiable and ambitious environmental criteria for products and services, based on a life-cycle approach and scientific evidence. In its Communication "Public procurement for a better environment" the Commission recommended the creation of a process for setting common GPP criteria. ${ }^{25}$ As a result, the official EU GPP Toolkit ${ }^{26}$ was developed and is continuously updated (see the product groups in Table 1).

These toolkits serve as inspiration for procurers seeking to implement green criteria into their procurement processes. The criteria in the toolkit follow the logic of procurement stages with specific phrasing and criteria suggestions. This allows

${ }^{25}$ COM (2008) 400: Communication from the Commission to the European Parliament, the Council, the European Economic and Social Committee and the Committee of the Regions, Public procurement for a better environment.

${ }^{26}$ GPP Toolkit [8]. 
Table 1 Identified methods of GPP Toolkit towards CPP (Ecolabel and Life-cycle costing). Source: own compilation based on the EU GPP Toolkit

\begin{tabular}{|c|c|c|c|c|}
\hline & $\begin{array}{l}\text { Technical } \\
\text { specifications } \\
\text { Art. 42(1) }\end{array}$ & $\begin{array}{l}\text { Selection } \\
\text { criteria Art. } 58\end{array}$ & $\begin{array}{l}\text { Award criteria } \\
\text { Art. } 67\end{array}$ & $\begin{array}{l}\text { Contract } \\
\text { clause Art. } 70\end{array}$ \\
\hline $\begin{array}{l}\text { Indoor cleaning } \\
\text { services }\end{array}$ & ECOL, LCC & ECOL & ECOL & \\
\hline $\begin{array}{l}\text { Computers, monitors, } \\
\text { tablets and } \\
\text { smartphones }\end{array}$ & ECOL, LCC & & ECOL, LCC & \\
\hline $\begin{array}{l}\text { Copying and graphic } \\
\text { paper }\end{array}$ & ECOL & $\mathrm{ECOL}$ & & \\
\hline $\begin{array}{l}\text { Data centres, server } \\
\text { rooms and cloud } \\
\text { services }\end{array}$ & ECOL, LCC & & & \\
\hline $\begin{array}{l}\text { Electrical and } \\
\text { electronic equipment } \\
\text { used in the health } \\
\text { care sector }\end{array}$ & & & LCC & \\
\hline Electricity & & & & ECOL \\
\hline $\begin{array}{l}\text { Food catering } \\
\text { services and vending } \\
\text { machines }\end{array}$ & ECOL & & ECOL, LCC & LCC \\
\hline Furniture & $\mathrm{ECOL}$ & & ECOL & \\
\hline $\begin{array}{l}\text { Imaging equipment, } \\
\text { consumables and } \\
\text { printing services }\end{array}$ & LCC & & LCC & LCC \\
\hline $\begin{array}{l}\text { Office building } \\
\text { design, construction } \\
\text { and management }\end{array}$ & LCC & LCC & & \\
\hline $\begin{array}{l}\text { Paints, varnishes and } \\
\text { road markings }\end{array}$ & ECOL, LCC & & ECOL, LCC & LCC \\
\hline $\begin{array}{l}\text { Public space } \\
\text { maintenance }\end{array}$ & ECOL & ECOL & & \\
\hline $\begin{array}{l}\text { Road design, } \\
\text { construction and } \\
\text { maintenance }\end{array}$ & & & LCC & \\
\hline $\begin{array}{l}\text { Road lighting and } \\
\text { traffic signals }\end{array}$ & LCC & & & \\
\hline Road transport & LCC & & ECOL, LCC & \\
\hline Sanitary tapware & ECOL & & & \\
\hline Textiles & ECOL, LCC & & ECOL & $\mathrm{ECOL}$ \\
\hline Toilets and urinals & LCC & & LCC & \\
\hline $\begin{array}{l}\text { Waste water } \\
\text { infrastructure }\end{array}$ & LCC & & LCC & LCC \\
\hline Water-based heaters & ECOL, LCC & & ECOL, LCC & ECOL \\
\hline
\end{tabular}


procurers to use the core or comprehensive criteria, even select from these. This flexibility allows the procurers to create "light" or "dark" green tenders, depending on the product group, market conditions, their attitude to risks etc. In practice we can see that using these criteria sets is very useful, but in most cases doesn't seem to give full support for the CE concept.

Each guideline assigns ideas to the most important green elements for each group of procurement items. Contracting authorities receive specific ideas mainly for the technical specification and award criteria, and to a lesser extent for the selection criteria and the contract clause.

The following is an overview of the legal instruments to which the ecolabel or life-cycle costing method is linked in each GPP criteria set. This is important because these two methods can indeed be used not only to green one element of the process but also to achieve a more environmentally beneficial situation in terms of market impact over the longer term.

As can be seen below, CPP methods are typically linked to the preparation of the technical specifications and are primarily built into the award criterion, as this can also give an advantage to those operators that have an ecolabel or the life-cycle cost becomes the basis for the award criterion. In the classification, we also took into account the differences between the various guidelines, as they are not written in exactly the same form, so in many cases, in our opinion, the use of the contract clause was intended in one way by the authors, but not reinforced by the contracting authority, e.g. the use of LCC is based on the fact that in the event of a deviation, there are legal consequences in the future if, for example, it costs significantly more to maintain a house. In the case of the selection criterion, it is particularly important that the ecolabel of a specialist or reference product, for example, can be part of the set of requirements, which are not typical requirements used in public procurement. It is no coincidence that these requirements are the least likely to be imposed by contracting authorities as part of the selection criterion.

Overall, the GPP Toolkit ${ }^{27}$ above offers forward-looking ideas and options, but the use of an ecolabel, for example, if it is done by the contracting authority in the interest of CPP, needs to be further considered, while life-cycle costing alone aims to ensure that all costs of performance are identified and thus the conditions set by the contracting authority are actually met. Similarly, these methods are highlighted by Sönnichsen and Clement ${ }^{28}$ in their research as core parts of the process of the transition towards circular public procurement. And Alhola et $\mathrm{al}^{29}$ refer to LCC in their research on the successful use of CPP, while Kristensen et $\mathrm{al}^{30}$ highlight the use of ecolabels in the context of CPP in their research on Danish municipalities.

In addition to technological requirements, the technical conditions and the conditions for assuming the guarantee, which are defined in order to avoid waste and unnecessary construction works, as well as the types of costs for maintenance needs, should be defined by the contracting authority, as all bidders have to price them.

\footnotetext{
${ }^{27}$ GPP Toolkit [8].

${ }^{28}$ Sönnichsen and Clement [20].

${ }^{29}$ Alhola et al. [1].

${ }^{30}$ Kristensen et al. [10].
} 
The LCC guidelines are similarly extended in public procurement, as they are not a procurement-specific solution requiring present value calculation. LCC, enabled by the guideline provisions, is a matter of concern for many researchers, given the need for a prepared contracting authority and serious preparation to obtain comparable offers which can be held to account during the performance of the contract. However, research findings suggest that the right conditions are needed for GPP to stimulate the internalisation of LCC in public procurement ${ }^{31}$.

Ecolabelling is a voluntary tool that supports sustainable consumption and production and is considered as a green marketing tool as well, by providing information to consumers. Because of the risks of greenwashing and the number of environmental claims arising, the International Standard Organization developed the 14020 series of standards which define three different types of environmental claims. The ISO Type- 1 labels ${ }^{32}$ are life-cycle based, meaning that each step of the product life cycle needs to have minimized environmental impact. The ecolabels in this category need to fulfil transparent and scientifically proven criteria and are certified by independent third parties, ensuring trustworthiness. ISO Type-1 labels play a particular role in GPP, since they can be used in the procurement process for verifying compliance. ${ }^{33}$ This makes the procurement process easier for contracting authorities and bidders alike.

The public procurement directives 34 "allow public purchasers to refer to a specific label or ecolabel when laying down the environmental characteristics of the works, goods or services they wish to purchase..." 35 under the following conditions: requirements should be linked to the product or service, the label is developed in a transparent procedure by an independent body with the contribution of a wide range of stakeholders; the criteria is objective and non-discriminatory, available for all interested parties, and other equivalent means of proof should be accepted.

Ecolabels are available for only a number of product groups - even so with all its limitations ${ }^{36}$, the use of these labels makes green purchasing much easier and gives significant support for the circular economy concept. As highlighted before, it should be noted that reverse logistics plays a crucial role in achieving fully circular business activities and closer cooperation between producers and end-consumers is necessary.

Requiring ISO Type-1 labelled products in public procurement ensures that the life cycle of the product is proven to have minimized negative environmental impact. The full criteria set of ISO Type-1 ecolabels provide significant support for the circularity of public procurement. In those product groups, where ISO Type-1 ecolabels exist, it would be beneficial to use them instead of any other supporting tool; however, there

\footnotetext{
${ }^{31}$ De Giacomo [2].

${ }^{32}$ For example Blue Angel, EU Ecolabel, Nordic Swan etc.

${ }^{33}$ Diófási-Kovács [3, 4].

${ }^{34}$ Directive 2014/24/EU of the European Parliament and of the Council of 26 February 2014 on public procurement and repealing Directive 2004/18/EC, Directive 2014/25/EU of the European Parliament and of the Council of 26 February 2014 on procurement by entities operating in the water, energy, transport and postal services sectors and repealing Directive 2004/17/EC.

${ }^{35}$ Public Procurement Reform Factsheet No. 7 [17], p. 1.

${ }^{36}$ Diófási-Kovács [4].
} 
are still stages of the life cycle which need collaborative solutions for truly circular public procurement.

The transition towards circular economy starts with designing the product or service. In the design phase there is a possibility to take circularity and sustainability into account, for example, by reducing the amount of raw materials, use of recycled materials, energy efficient production, ensuring easy dismantling for recycling, supporting the take back of the product with creating a motivating business model for customers etc. The design phase is important in terms of innovation and collaboration with future consumers.

Production and manufacturing are important in terms of reducing the environmental impact of products, since this pre-use phase significantly contributes to the negative environmental effects of a product's life cycle. In this phase energy efficiency, closed material loops of production waste, resource efficiency, water conservation etc. can be mentioned as solutions supporting circularity.

Distribution is an overarching activity in a product's life cycle in the global economy. The transportation of raw materials, different parts and products, the distribution network towards customers has strong environmental impacts. The ecolabel criteria do not address this issue since it falls outside the scope of the relationship of the certification body and the producer. These emissions might be reduced by extra requirements in the procurement process (green procurement of logistics services, supply chain level collaboration is needed).

The consumption phase starts when the product reaches its customer. In this phase guidance for the correct use of the product helps consumers move towards efficiency, and the life-cycle cost considerations are relevant also. The producers of the product are not involved in this stage of the product's life cycle. It is the responsibility of the customer to reuse, repair or recycle the product.

The end-of-life stage starts with the collection of waste for recycling or disposal. This stage is also heavily relying on the consumer of the product, although circular solutions and business models based on buyer-user collaboration can enhance reverse material flows. The associated environmental impacts can be reduced with collaborative business solutions.

As we can see in Table 2, neither of the tools cover the whole life cycle in terms of requirements, but the ISO Type-1 ecolabel gives more support for circular public procurement if used within technical specifications or among award criteria.

In the case of life-cycle costing, the GPP toolkit ${ }^{37}$ has introduced a new feature that goes beyond its original purpose. The rules described earlier are explicitly discussed in Art. 68 of Directive 2014/24 as part of the award criteria. The GPP Toolkit ${ }^{38}$ clearly puts the emphasis on the preparation of the procedure and does not interpret the LCC only as part of the evaluation aspect. This is significant because, if the nature of the subject of the procurement allows, the design of the cost structure, the contracting authority's requirements in terms of materials and technologies used, which it specifies in the technical specifications, have a direct impact on the LCC. At the execution phase, it is also subject to the fact that the prices and costs agreed

\footnotetext{
${ }^{37}$ GPP Toolkit [8].

${ }^{38}$ GPP Toolkit [8].
} 
Table 2 Comparison of the requirements of the GPP Toolkit ${ }^{\mathrm{a}}$ and the EU Ecolabel ${ }^{\mathrm{b}}$ in light of circularity and product life cycle - Example of copying and graphic paper. Source: own compilation, based on: GPP Europe, 2021 and EU Ecolabel 2011/332/EU

\begin{tabular}{ll}
\hline $\begin{array}{l}\text { Product lifecle } \\
\text { stages in the } \\
\text { circular economy } \\
\text { model }\end{array}$ & $\begin{array}{l}\text { EU Ecolabel criteria } \\
\text { EU Ecolabel 2011/332/EU }\end{array}$ \\
\end{tabular}

$\begin{array}{ll}\text { Design } & - \\ \text { Raw material } & \begin{array}{l}\text { Core + Comprehensive: The virgin } \\ \text { fibre for pulp production shall } \\ \text { come from legal sources. }\end{array}\end{array}$

Ecolabel criteria sets are a framework for product design

Production and Core + Comprehensive: The paper manufacturing must be at least Elementary Chlorine Free (ECF). Comprehensive: Products which meet the ecological criteria of the EU Ecolabel directly related to paper production

Criterion 3 - Fibres: sustainable forest management

Criterion 1 - Emissions to water and air

Criterion 2 - Energy use

Criterion 4 - Excluded or limited substances and mixtures

Distribution, transportation

Consumption,

Criterion 6 - Fitness for use

use

Criterion 7 - Information on

packaging

Criterion 8 - Information on the

EU Ecolabel

Collection

Criterion 5 - Waste management

Recycling

Disposal

${ }^{\text {a } G P P}$ Toolkit [8]

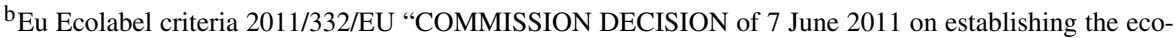
logical criteria for the award of the EU Ecolabel for copying and graphic paper http://eur-lex.europa.eu/ LexUriServ/LexUriServ.do?uri=OJ:L:2011:149:0012:0024:EN:PDF”

in the contract resulting from the procedure are accountable, for example, if the tender included a rate of subsequent costs, any deviation from this rate may likewise be accountable to the successful tenderer.

Overall, the forward-looking ideas in the GPP Toolkit ${ }^{39}$ help market players forward on the path to CPP, but are not suitable for automatic application to achieve the objectives of the EU Green Deal and the Circular Action Plan. This requires a stronger CPP approach in procurement preparation, communication with market players to ensure competition, and direct linking of the legal instruments of public procurement to enable contracting authorities to encounter techniques to support their procedures on the path to CPP with low risk of redress.

${ }^{39}$ GPP Toolkit [8]. 


\section{Conclusion}

The EU Green Deal ${ }^{40}$ and the European Circular Economy Action Plan ${ }^{41}$ show the way forward for improving public procurement. However, the tools available need to be transposed into law in order to be truly effective. The general application of green criteria from the preparation of the procedure, through the conduct of the procedure, to the performance and monitoring of the contract, will accompany the process throughout. The preliminary market consultation, the grounds for exclusion, the selection and the award criteria, the technical specifications, the contractual content of the contract notice can all contain green elements. A price that is disproportionately low due to environmental pollution, or a modification of a previously achieved pollutant emission in a contract modification, all have an indirect relevance for the environment. The GPP Toolkit and the corresponding EU Directives set out two instruments whose application has real added value in terms of circular public procurement. These are the use of ecolabelling and life-cycle costing. Our article identifies these two methods from a legal and applicability point of view, pointing out that the application of green criteria requires a solution that can be used to generate continuous green power during preparation, tendering and contract execution, to be monitored and followed up and - after lessons have been learned - to be used in subsequent procedures.

The continuous development of the official EU GPP Toolkit is beneficial for procurers and suppliers alike - standing for clear and available messages which determine the direction for further development instead of ever-changing expectations. Green procurement and the use of the GPP Toolkit needs to be further supported by practical training and development of the official GPP Toolkit. The goal set by the European Circular Economy Action Plan can only be achieved if market players communicate and cooperate with one another. Similarly, market dialogue and cooperation between procurers is referred to in Alhola et $\mathrm{al}^{42}$. Witjes and Lozano ${ }^{43}$ argue that collaboration between procurers and suppliers throughout the procurement process can lead to more environmentally beneficial outcomes, whilst promoting the development of new, more sustainable business models. Similarly, according to Ntsondé and Aggeri ${ }^{44}$, public procurement can stimulate innovation regarding CPP and create opportunities for collective innovative practices. Kristensen et $\mathrm{al}^{45}$ advocate collaboration with supply chain actors in circular public procurement. Rosell's ${ }^{46}$ research suggests that better governance, if linked to GPP adoption, can provide further opportunities and momentum for moving towards CPP.

In case of circular public procurement, collaboration and innovation are crucial. This might happen in the form of discussing the demand in collaboration with suppli-

\footnotetext{
${ }^{40}$ European Green Deal [5].

${ }^{41}$ European Circular Economy Action Plan [6].

${ }^{42}$ Alhola et al. [1].

${ }^{43}$ Witjes and Lozano [22].

${ }^{44}$ Ntsondé and Aggeri [15].

${ }^{45}$ Kristensen et al. [10].

${ }^{46}$ Rosell [19].
} 
ers and creating a criteria set with the supplier, focusing on the best value for money considering the life-cycle costs and maintaining close cooperation in the pre-award and post-award phases. Collaborative solutions can be difficult but not impossible in cases of public procurement, where fairness of competition should be provided for in every stage of the procurement process.

Acknowledgements This work was created on the basis of an NKFI commission under project K 137794.

Funding Note Open access funding provided by Corvinus University of Budapest.

Open Access This article is licensed under a Creative Commons Attribution 4.0 International License, which permits use, sharing, adaptation, distribution and reproduction in any medium or format, as long as you give appropriate credit to the original author(s) and the source, provide a link to the Creative Commons licence, and indicate if changes were made. The images or other third party material in this article are included in the article's Creative Commons licence, unless indicated otherwise in a credit line to the material. If material is not included in the article's Creative Commons licence and your intended use is not permitted by statutory regulation or exceeds the permitted use, you will need to obtain permission directly from the copyright holder. To view a copy of this licence, visit http://creativecommons.org/licenses/by/ $4.0 \%$.

\section{References}

1. Alhola, K., Ryding, S.O., Salmenperä, H., Busch, N.J.: Exploiting the potential of public procurement: opportunities for circular economy. J. Ind. Ecol. 23(1), 96-109 (2019)

2. De Giacomo, M.R., Testa, F., Iraldo, F., Formentini, M.: Does green public procurement lead to life cycle costing (LCC) adoption? Eur. J. Purch. Supply Manag. 25(3), 100500 (2019)

3. Diófási-Kovács, O.: Investigating the success factors for green procurement-developing a toolkit and methodology to support the integration of green considerations into domestic procurement practices. PhD dissertation (2016). https://repozitorium.omikk.bme.hu/handle/10890/1515

4. Diófási-Kovács, O.: Public procurement and the circular economy. In: Tibor Karlovitz, J. (ed.) Essays in Economics and Business Studies, pp. 41-48. International Research Institute, Komárno (2017). ISBN: 978-80-89691-42-5

5. European Green Deal: Communication from the Commission to the European Parliament, the European Council, the Council, the European Economic and Social Committee and the Committee and the Committee of the Regions: The European Green Deal COM/2019/640 final (2019)

6. European Circular Economy Action Plan: Communication from the Commission to the European Parliament, the Council, the European Economic and Social Committee and the Committee of the Regions - a new Circular Economy Action Plan, for a cleaner and more competitive Europe, Brussels, 11.3.2020, COM(2020) 98 final (2020)

7. GPP Guideline: Public Procurement for a Circular Economy - Good Practice and Guidance, 2017 (2017). https://ec.europa.eu/environment/gpp/pdf/CP_European_Commission_Brochure_ webversion_small.pdf

8. GPP Toolkit Green Public Procurement Toolkit of the EU. http://ec.europa.eu/environment/gpp/eu_ gpp_criteria_en.htm

9. Halonen, K.M.: Is public procurement fit for reaching sustainability goals? A law and economics approach to green public procurement. Maastricht. J. Eur. Comp. Law (2021). https://doi.org/10.1177/ 1023263 X211016756

10. Kristensen, H.S., Mosgaard, M.A., Remmen, A.: Circular public procurement practices in Danish municipalities. J. Clean. Prod. 281, 124962 (2021)

11. Lewandowski, M.: Designing the business models for circular economy-towards the conceptual framework. Sustainability 8, 43 (2016). http://www.mdpi.com/journal/sustainability

12. Meehan, J., Bryde, D.: Sustainable procurement practice. Bus. Strategy Environ. 20(2), 94-106 (2011)

13. Moen, R.D., Norman, C.L.: Clearing up myths about the Deming cycle and seeing how it keeps evolving (2010). http://www.apiweb.org/circling-back.pdf 
14. Murray, A., Skene, K., Hayne, K.: The circular economy: an interdisciplinary exploration of the concept and application in a global context. J. Bus. Ethics 140, 369-380 (2017)

15. Ntsondé, J., Aggeri, F.: Stimulating innovation and creating new markets-the potential of circular public procurement. J. Clean. Prod. 308, 127303 (2021)

16. Pouikli, K.: Towards mandatory Green Public Procurement (GPP) requirements under the EU Green Deal: reconsidering the role of public procurement as an environmental policy tool. ERA Forum 21(4), 699-721 (2021)

17. Public Procurement Reform Factsheet No. 7: Green Public Procurement. https://eufunds.gov.mt/en/ EU\%20Funds\%20Programmes/Financial\%20Control\%20Unit/Documents/Links\%20and\%20 downloads/Fact\%20sheets/fact-sheet-07-environmental_en.pdf

18. Rainville, A.: Stimulating a more circular economy through public procurement: roles and dynamics of intermediation. Res. Policy 50(4), 104193 (2021)

19. Rosell, J.: Getting the green light on green public procurement: macro and meso determinants. J. Clean. Prod. 279, 123710 (2021)

20. Sönnichsen, S.D., Clement, J.: Review of green and sustainable public procurement: towards circular public procurement. J. Clean. Prod. 245, 118901 (2020)

21. Towards a Circular Economy: Communication from the Commission to the European Parliament, the European Economic and Social Committee and the Committee of the Regions. Towards a circular economy: a zero waste programme for Europe /* COM/2014/0398 final */ (2014)

22. Witjes, S., Lozano, R.: Towards a more Circular Economy: proposing a framework linking sustainable public procurement and sustainable business models. Resour. Conserv. Recycl. 112, 37-44 (2016)

Publisher's Note Springer Nature remains neutral with regard to jurisdictional claims in published maps and institutional affiliations. 